Poznańskie Studia Teologiczne 29(2015), s. 17-25.

doi: $10.14746 /$ pst.2015.29.2

Gerald O'Collins ${ }^{1}$

Australian Catholic University

University of Divinity Melbourne

\title{
Interpreting the Documents of Vatican II Integrally
}

In a study of literary theory that first appeared in 1967 and so two years after the close of the Second Vatican Council (1962-1965), Eric Donald Hirsch argued that a text means and continues to mean only what its author originally intended to communicate (the intentio auctoris). As he put it tersely, 'a text means what its author meant'. ${ }^{2}$ He supposed this meaning to remain immutable, and simply resistant to historical change and re-interpretation in the ever-changing contexts of human history. For Hirsch, his predecessors, and his followers, 'meaning is unchangeable because it is always the intentional act of an individual at some particular point in time'. ${ }^{3}$ By reducing meaning to the intentions of authors, this view has come to be labelled 'the intentional fallacy'.

\section{Interpreting the Vatican II Documents through Authorial Intention}

Although generally unaware of Hirsch's Validity of Interpretation, many commentators on the sixteen documents produced by Vatican II have followed suit. Often without thinking through any theory of interpretation, they have understood these four constitutions, nine decrees, and three declarations to mean only what the Vatican II authors consciously intended to communicate (the intentio auctoris or auctorum).

We have abundant information about what the bishops and others who served on the conciliar commissions wanted to convey in the texts they drafted and then revised. In a kind of committee authorship they evaluated what ideas were to be

\footnotetext{
${ }^{1}$ Gerald O'Collins, SJ, AC, taught fundamental and systematic theology at the Pontifical Gregorian University (Rome) from 1973 to 2006. He is now an Adjunct Professor of the Australian Catholic University and Research Fellow of the University of Divinity (Melbourne). He has authored or co-authored over sixty books, which include, most recently The Second Vatican Council on Other Religions (Oxford University Press) and the Second Vatican Council: Message and Meaning (Liturgical Press).

${ }^{2}$ E.D. Hirsch, Jr., Validity in Interpretation, (New Haven, Conn.: Yale University Press, 1967, 1.

${ }^{3}$ T. Eagleton, Literary Theory: An Introduction, $2^{\text {nd }}$ edn, Oxford: Blackwell, 1996, 61.
} 
included, how they were to be expressed, and on what basis they should be endorsed. When they distributed the texts to those attending Vatican II, they justified their sources and formulations through the notes provided and the 'relations' delivered in plenary sessions of the Council.

All of this can be studied in the published acts of Vatican II, the unpublished records from the commissions (kept in a special Vatican archive), scholarly studies of particular documents, ${ }^{4}$ diaries,${ }^{5}$ and other personal records that have become available.

Those who, like Hirsch, over-emphasize the intentions of authors limit themselves to establishing what was in the minds of the members of those Vatican II commissions that prepared and revised the texts voted on and eventually accepted by the Council fathers. Valid interpretation then becomes a matter of meaning being conveyed from one set of minds, primarily the members of those commissions, to the minds of current readers. The Council's texts function simply as a bridge between the minds of the authors and those of the readers. The latter have the role of grasping and restating what the authors consciously wished to convey. ${ }^{6}$

Such a Hirsch-style approach to the documents of Vatican II stands in tension with the views of innumerable literary critics and, one must add, philosophers, biblical exegetes, and canon lawyers. Yes, by all means let us study the evidence that illuminates the intentions of the Council's authors. But it is at our peril that we forget that those authors could hardly foresee how their texts would be received, interpreted, and put into practice (or, in such cases as the collegiality of the bishops taught in the Dogmatic Constitution on the Church, implemented only partially). The history of the texts and their readers must enter any integral interpretation of the Vatican II documents.

But we need an integral view that attends also to the conciliar texts in themselves (the intentio textus ipsius) and how they have been received, interpreted, and implemented by countless readers around the world (the intentio legentis). It is a commonplace among literary critics and philosophers that texts, once published, enjoy a certain independence from their authors. As Paul Ricoeur wrote, 'the meaning of what has been written down is henceforth separate from the possible intentions of the authors... What we call the semantic autonomy of the text

\footnotetext{
${ }^{4}$ See e.g. R. Burigana, La Bibbia nel concilio: La redazione della costituzione 'Dei Verbum' del Concilio Vaticano II, Bologna: Mulino, 1998. S. Scatena, La fatica della libertà: l'elaborazione della dichiarazione 'Dignitatis humanae' sulla libertà humana del Vaticano II, Bologna: Il Mulino, 2003.

${ }^{5}$ See e.g. Y. Congar, My Journal of the Council, trans. Mary John Ronayne and Mary Cecily Boulding Collegeville, Minn.: Liturgical Press, 2012.

${ }^{6}$ This view recalls R.G. Collingwood's theory of historical research as 're-enacting' the past in our own mind, even to the point of 're-thinking' for oneself 'the thought' of long dead authors; see his The Idea of History, New York: Oxford University Press, 1956, 282-302.
} 
means that the text unfolds a history distinct from that of the authors. ${ }^{7}$ When texts are read in new cultural and historical contexts, meanings contained in them come to light and can go beyond what the original authors ever consciously intended.

In short, any adequate interpretation of the Vatican II documents requires attention not only to the authors and their intentions (the intentio auctoris), but also to the history of the texts (the intentio textus ipsius) and their readers who help shape that history through an ongoing reception (the intention legentis).

\section{Authors as Privileged Interpreters?}

Unlike ancient writers (who rarely if ever commented on the meaning of the works they composed) and unlike some modern authors, like T. S. Eliot, ${ }^{8}$ many of the periti or official experts who served at Vatican II subsequently wrote or contributed to commentaries on documents they had earlier helped to compose and revise. A unilateral emphasis on the intentio auctoris) makes them privileged interpreters of the texts they wrote and revised for the Council. That would confer a special value on the chapters which Georges Anawati, Yves Congar, Aloys Grillmeier, Gérard Philips, Karl Rahner, Joseph Ratzinger, Otto Semmelroth, and other periti who had served on commissions at Vatican II contributed to Herbert Vorgrimler's five-volume commentary on the Council documents and to the twenty-four volumes of commentary coming from the publishing house of Cerf (1966-1970). ${ }^{9}$ In what they wrote for such joint publications or by themselves, ${ }^{10}$ are such Council authors uniquely privileged commentators on the documents they fashioned?

Many critics and even some authors themselves argue, however, that authors are not necessarily the most reliable guides to interpreting what they compose. Famously T. S. Eliot refused to comment on the meaning of his works. When Robert Schumann composed and played a new piece, someone asked him what it meant. Schumann did not say a word. He simply sat down again at the piano and played the piece a second time. Readers (and, in the case of music, hearers) may understand texts better than the persons who wrote them. Sometimes or even often authors do not adequately know what they meant when they wrote what

\footnotetext{
${ }^{7}$ See e.g. P. Ricoeur, Hermeneutics, trans. D. Pellauer, Cambridge, UK: Polity Press, 2013, 12.

${ }^{8}$ On Eliot's refusal to comment on the meaning of his works, see E.D. Hirsch, Validity in Interpretation, 10-11.

${ }^{9}$ H. Vorgrimler (ed.), Commentary on the Documents of Vatican II, 5 vols., London: Burns \& Oates, 1967-69. The Cerf commentaries opened with Y. Congar et al. (eds.), L'Église et Vatican II, 3 vols., Paris: Cerf, 1966-67.

${ }^{10}$ For instance, G. Philips, L'Église et son mystère au II Concile de Vaticane: Histoire, texte, et commentaire del Constitution 'Lumen Gentium', 2 vols., Paris: Desclée, 1967.
} 
they did. Immanuel Kant has proved a classic exponent of this point of view. Apropos of Plato's theory of ideas, he wrote: 'when we compare the thoughts that an author expresses about a subject, in ordinary speech as well as in writings, it is not all unusual to find that we understand him [!] better then he understood himself'. ${ }^{11}$

As much as any writers or composers, the Vatican II authors could hardly foresee how their texts would be received, interpreted, and practised. In December 1963 the conciliar authors of the Constitution on the Sacred Liturgy, Sacrosanctum Concilium, had no way of knowing in advance how their collegial instructions about revising and translating liturgical texts would be put into practice (and sometimes thwarted by Roman authorities). Much of the history of its interpretation and reception could hardly have been foreseen by the original authors of Sacrosanctum Concilium.

\section{Two Examples}

The Declaration on the Relation of the Church to Non-Christian Religions, Nostra Aetate, offers an intriguing example of fresh meaning of conciliar texts opening up in the aftermath of Vatican II. The shortest of all the Council's documents and the one that had the most troubled passage to its final form, it was given the lowest grade of authority as a 'mere' declaration. But its subsequent, very positive reception by Catholics and others continues to give this text a meaning and significance far beyond what its authors ever imagined. Take, for instance, the positive thing the declaration said about Muslims (no. 3) and then about Jews (nos. 4-5). These texts have taken on further meaning from subsequent history.

St John Paul II was the first pope to pray in a mosque, as he did in Damascus in 2001. Years earlier, when returning from a 1985 visit to Zaire, Kenya, and some other African nations, he went home to Rome via Morocco. At the invitation of King Hassan II of Morocco, he spoke to a crowd of over one hundred thousand young Muslims about the religious and moral values common to Christian and Muslim faith. ${ }^{12}$ Since the days when Muhammad launched Islam more than 1,300 years ago, no pope has ever been invited by a Muslim leader to do anything like that. ${ }^{13}$

${ }^{11}$ I. Kant, Critique of Pure Reason, trans. P. Guyer and A.W. Wood, Cambridge, UK: Cambridge University Press, 1998, 396.

${ }^{12}$ Acta Apostolicae Sedis 78 (1986), 95-104; English trans. G. O’Collins, D. Kendall, and J. LaBelle (eds.), John Paul II: A Reader, Mahwah, NJ: Paulist Press, 2007.

${ }^{13}$ See further A. Mazur, L'insegnamento di Giovanni Paolo II sulle altre religioni, Rome: Editrice Pontificia Università Gregoriana, 2004, 92-100. 
The teaching of Nostra Aetate opened the door for a reconciliation with the Jewish people that was practised, often dramatically, during the pontificate of St John Paul II (1978-2005) and now (from 2013) by Pope Francis. The visit of John Paul II to the synagogue in Rome (1986) and then to Israel (20-26 March 2000) were important landmarks in renewed relations with the Jewish people. In 1994 he hosted a Holocaust memorial concert in the Pope Paul VI Memorial Hall at the Vatican. The Royal Philharmonic Orchestra came from London and was conducted by Gilbert Levine, a Brooklyn-born American Jew. John Paul II sat with the chief rabbi of Rome, Elio Toaff, who had brought with him his congregation. The concert was part of the Pope's personal mission to keep alive at the centre of the Catholic world the memory of the Holocaust. He also arranged for the Kaddish, the traditional Jewish prayer for the dead, to be recited.

Four years later, on 16 March 1998, the Vatican's Commission for Religious Relations with the Jews published 'We Remember: a Reflection on the Shoah', which quoted from John Paul II's 1986 speech in the Roman synagogue and, drawing on what Nostra Aetate taught against anti-Semitism, stated: 'the spoiled seeds of anti-Judaism and anti-Semitism must never again be allowed to take root in any human heart'. In an accompanying letter, John Paul II hoped that this new document would 'enable memory to play its necessary part in the process shaping a future in which the unspeakable iniquity of the "Shoah" will never again be possible'. ${ }^{14}$

The pilgrimage of Pope Francis to the Holy Land and dialogue with Shimon Peres and Mahmoud Abbas in the Vatican gardens add meaning to the text of Nostra Aetate. Moving beyond the declaration's renunciation of centuries of anti-Semitism, Pope Francis teaches: 'as Christians, we cannot consider Judaism as a foreign religion... Dialogue and friendship with the children of Israel are part of the life of Jesus' disciples' ${ }^{15}$ What Pope Francis has said and done, as in the case of John Paul II, shapes the context in which current readers derive meanings from Nostra Aetate.

Implementation of the Council's mandates ensured the ongoing life of another text, the Decree on Ecumenism of 21 November 1964. Unitatis Redintegratio ushered in the creation of many official bilateral dialogues between the Catholic Church and other Christian churches and ecclesial communities. At a national and international level, the work continues, sometimes with momentous results.

The Catholic-Lutheran dialogue produced such an achievement in the 1999 'Joint Declaration on the Doctrine of Justification'. It was accepted by the Catholic Church and the Lutheran World Federation, and in large part laid to rest di-

\footnotetext{
${ }^{14}$ Origins 40/27 (1998), 670-75.

${ }^{15}$ Evangelii Gaudium, Vatican City: Libreria Editrice Vaticana, 2013, nos. 247-48.
} 
visions over God's saving gift of righteousness, a central issue in the debates with the sixteenth century Reformers.

Chains of meaning open up when we re-read Unitatis Redintegratio in the context of post-Vatican II ecumenical developments. The call for the 'continual reformation' and 'renewal' of the Catholic Church (no. 5), for instance, by aiding and illuminating inter-church dialogues and documents, has thrown open and enriched the meaning of that language. Replacement of terminology also plays its role. Where UR, like other official Catholic documents of the time, referred to other Christians as 'separated brethren' (twice, for instance, in no. 9), Pope Francis, by speaking rather of 'pilgrims journeying alongside one another', ${ }^{16}$ has readjusted judgments on the meaning of descriptions for ecumenical partners.

\section{Biblical Interpretation}

Interpreters of the Council's documents would well be advised to follow the example of those engaged with biblical studies. In his 1943 encyclical Divino Afflante Spiritu, Pope Pius XII encouraged the 'historical-critical method,' which aimed to establish the literal meaning or meaning intended by the authors of the sacred texts. Nevertheless, as a 1993 document of the Pontifical Biblical Commission, The Interpretation of the Bible in the Church, spelled out at length, interpreters of the scriptures need to go beyond the intentions of the original authors, the intentio auctoris or auctorum. They should also approach the texts through the history of their reception in the context of tradition (the intentio textus), as well as apply methods that yield fresh meanings coming from the readers of scripture (intentio legentis). In this context, the 1993 document noted with apparent approval what Ricoeur called a certain 'distancing' or distinguishing between author and text, as well as between text and successive readers. ${ }^{17}$

Unquestionably, the documents of Vatican II differ from scriptural texts inasmuch as they are not inspired and do not form together a closed conciliar canon. ${ }^{18}$ Nevertheless, what the 1993 document from the Biblical Commission presents about interpreting scriptural texts can obviously be applied to the interpretation of texts produced by church councils and, in particular, by the Second Vatican Council. In both cases, interpreters should investigate, to the extent they can, what the original authors had in mind when they wrote what they did (intentio auctoris). But in both cases it is insufficient to leave matters at that. We need

\footnotetext{
${ }^{16}$ Evangelii Gaudium, no. 244.

${ }^{17}$ Pontifical Biblical Commission, The Interpretation of the Bible in the Church (Vatican City: Libreria Editrice Vaticana, 1993), 74-75.

18 The teaching of councils of the Church has been developed and, at times (e.g. in nonessential matters), changed. There is no such thing as a closed canon of the twenty-one general councils that have already taken place.
} 
to attend also to the multiple meanings that emerge when we study the history of the text's reception (intentio textus) and the insights of readers with their different presuppositions, questions, and expectations (intentio legentis). This involves applying what The Interpretation of the Bible in the Church indicates about a triple handling of the scriptural texts. ${ }^{19}$

\section{Help from Canon Law}

Finally, the sixteen documents of Vatican II do not form a code of canon law. But those who interpret them should learn not only from literary critics, philosophers, and biblical scholars but also from longstanding legal theory and practice. The interpretation of statutes and constitutions looks beyond the intentions of those who originally framed them to construe what the texts, their language, and their purpose (to be determined by context and history) mean. ${ }^{20}$

A legal friend remarked to me: "The idea of a law frozen in amber according to the mind of its makers finds little support in the 1983 Code of Canon Law or elsewhere.' He recalled canon 17 of the Code. 'The mind of the legislator' should be considered only if 'recourse to the text and its purpose have failed.' It comes not first but only at the very end of the canon:

Ecclesiastical laws are to be understood according to the proper meaning of the words considered in their text and context. If the meaning remains doubtful or obscure, there must be recourse to parallel places, if there be any, to the purpose and circumstances of the law, and to the mind of the legislator.

For good measure, my friend pointed to canon 27. 'Custom,' and not the mind of the legislator, 'is the best interpreter of laws.'

\section{Conclusion}

Legal studies, along with literary, philosophical, and biblical studies, form areas of research and knowledge that are distinct from the study of councils. But they are not so distinct as to exclude some general principles and methods of interpretation that apply, at least analogously, to all four areas.

It is high time that many commentators on the Council's texts caught up with the principles and methods of interpretation practised elsewhere. The reception

\footnotetext{
${ }^{19}$ The Biblical Commission distinguished between the historical-critical method (34-41), approaches to the text $(56-57,86-100)$, and methods involving readers (41-50). What the Commission said corresponded, respectively, to the intentio auctoris, the intentio textus, and the intentio legentis, even if it did not use this terminology.

${ }^{20}$ See e.g. Y. Kim, Statutory Interpretation: General Principles and Recent Trends, New York: Nova Science Publishers, 2009; W.D. Popkin, A Dictionary of Statutory Interpretation, Durham, NC: Carolina Academic Press, 2007.
} 
of the Vatican II texts (or failure to receive them) in the post-1965 history of the church influences current reading of these documents. Our search for the meaning of the conciliar texts should take us beyond the intentions of the original authors.

The publication of Nostra aetate in 1965, as we saw above, signalled the start of serious official Catholic engagement with Judaism, Islam and other living faiths. Subsequent statements on Christian-Jewish and Christian-Muslim relations, not to mention the actions of John Paul II, Pope Francis, and countless other Christian leaders and believers, have created the new context in which we read, interpret, and apply the declaration on the church's relations to other faiths.

Nostra aetate presents a spectacular case of how the interpretation and implementation of Vatican II texts have pressed beyond the authorial intent of the original drafters to unfold the meaning that the texts have also received from successive generations of readers. Those who continue to privilege unilaterally the minds of the committees that framed the Council's documents should pause to take advice from literary critics, philosophers, biblical scholars, and canon lawyers.

\section{Summary}

Commentators on the sixteen documents from the Second Vatican Council (1962-65) regularly understand the meaning of those texts to derive merely from the intentions of their authors., those bishops and experts who drafted and revised the documents for the council fathers (intentio auctoris). The texts mean what the authors meant. This is to ignore the meaning that derives from readers (intentio legentis) and the ongoing history of the text itself (intentio textus ipsius). Literary, philosophical, biblical, and legal studies illustrate how the quest for meaning takes us beyond the author of a text to recognize that the integral meaning of any text is also shaped by the history of its interpretation and readers.

\section{Streszczenie}

Komentatorzy szesnastu dokumentów Soboru Watykańskiego II (1962-65) rozumieją znaczenie tych tekstów jako wypływające z intencji ich autorów - biskupów i ekspertów - którzy opracowywali i nanosili poprawki do dokumentów przeznaczonych dla soborowych ojców (intentio auctoris). Teksty wyrażają to, co autorzy mieli na myśli. Taka interpretacja pomija znaczenie, które jest owocem odczytania tekstu przez czytelników (intentio legentis), oraz trwającą historię samego tekstu (intentio textus ipsius). Studia literackie, filozoficzne, biblijne oraz prawnicze ukazują, że dążenie do odkrycia znaczenia każdego tekstu musi uwzględniać również jego interpretację kształtowaną poprzez historię oraz przez jego czytelników.

\section{Keywords}

The Second Vatican Council, Documents, Interpretation, intentio auctoris, intentio legentis, intentio textus ipsius

\section{Slowa kluczowe}

Sobór Watykański II, dokumenty, interpretacja, intentio auctoris, intentio legentis, intentio textus ipsius 


\section{Bibliography}

Acta Apostolicae Sedis 78 (1986), 95-104; English trans. G. O’Collins, D. Kendall, and J. LaBelle (eds.), John Paul II: A Reader, Mahwah, NJ: Paulist Press, 2007.

Burigana R., La Bibbia nel concilio: La redazione della costituzione 'Dei Verbum' del Concilio Vaticano II, Bologna: Mulino, 1998.

Collingwood R.G., The Idea of History, New York: Oxford University Press, 1956.

Commentary on the Documents of Vatican II, H. Vorgrimler (ed.), 5 vols., London: Burns \& Oates, 1967-1969.

Congar Y., My Journal of the Council, trans. M. J. Ronayne and M. C. Boulding, Collegeville, Minn.: Liturgical Press, 2012.

Eagleton T., Literary Theory: An Introduction, $2^{\text {nd }}$ edn, Oxford: Blackwell, 1996, 61.

Evangelii Gaudium, Vatican City: Libreria Editrice Vaticana, 2013.

Hirsch E.D., Jr., Validity in Interpretation, New Haven, Conn.: Yale University Press, 1967, 1.

Kant I., Critique of Pure Reason, trans. P. Guyer and A.W. Wood, Cambridge, UK: Cambridge University Press, 1998.

Kim Y., Statutory Interpretation: General Principles and Recent Trends, New York: Nova Science Publishers, 2009.

L'Église et Vatican II, Y. Congar et al. (eds.), 3 vols., Paris: Cerf, 1966-1967.

Mazur A., L'insegnamento di Giovanni Paolo II sulle altre religioni, Rome: Editrice Pontificia Università Gregoriana, 2004.

Origins 40/27 (1998), 670-75.

Philips G., L'Église et son mystère au II Concile de Vaticane: Histoire, texte, et commentaire del Constitution 'Lumen Gentium', 2 vols., Paris: Desclée, 1967.

Pontifical Biblical Commission, The Interpretation of the Bible in the Church, Vatican City: Libreria Editrice Vaticana, 1993.

Popkin W.D., A Dictionary of Statutory Interpretation, Durham, NC: Carolina Academic Press, 2007.

Ricoeur P., Hermeneutics, trans. D. Pellauer, Cambridge, UK: Polity Press, 2013.

Scatena S., La fatica della libertà: l'elaborazione della dichiarazione 'Dignitatis humanae’ sulla libertà humana del Vaticano II, Bologna: Il Mulino, 2003. 